\title{
Molecular Characterization and Antibiotic Susceptibility of Edwardsiella tarda isolated from Farmed Nile Tilapia and African Catfish from Wakiso, Uganda
}

\author{
M. Nantongo ${ }^{1,3, *}$, E. M. Mkupasi ${ }^{1}$, D. K. Byarugaba ${ }^{2}$, S. P. Wamala ${ }^{2}$, R. H. Mdegela ${ }^{1}$, J. K. \\ Walakira $^{3}$ \\ ${ }^{1}$ College of Veterinary and Medical Sciences, Sokoine University of Agriculture, Tanzania. \\ ${ }^{2}$ College of Veterinary Medicine, Animal Science and Biosecurity, Makerere University. \\ ${ }^{3}$ National Fisheries Resources Research Institute-NARO, Uganda.
}

*Corresponding author. @ myayeri15@gmail.com

\begin{abstract}
This study was conducted to isolate and characterize Edwardsiella tarda (E. tarda) and assess its antimicrobial susceptibility. The bacterium was isolated in Wakiso District, Uganda, from symptomatic and asymptomatic Nile tilapia and African catfish raised in earthen ponds, tanks and cages between September 2016 and February 2017. The bacterium was then identified using conventional biochemical tests and API 20E test kits and characterized by sequencing $16 \mathrm{~S} r R N A$ gene. The antibiotic susceptibility of 16 drugs was established using the Kirby BeurDisc diffusion method. Eight $E$. tarda isolates were identified using conventional biochemical tests but only one isolate was confirmed to be $E$. tarda by PCR. Phylogenetic analysis indicated a distant relationship with other 16S $r R N A$ gene sequences retrieved from the GenBank. Six virulence genes (CitC, muk, $\operatorname{gadB}, \mathrm{katB}$, esaV, and $\operatorname{fim} A$ ) that enhance bacterial survival and pathogenesis in the host were detected. The isolate registered low levels of antibiotic resistance as it was resistant only to Oxacillin, Vancomycin and Penicillin, to which it is intrinsically resistant. This implies low antibiotic usage in aquaculture in the area. Despite its low occurrence, presence of virulent genes in E. tarda indicates its potential to affect fish and human health.
\end{abstract}

Keywords: Aquaculture, Edwardsiella tarda, Phylogeny, Virulence

\section{Introduction}

Aquaculture in Uganda is increasing with a production of about 101659 tonnes (FAO, 2018). However, intensification of fish farming to meet the increasing fish demand is challenged with disease outbreaks (Bondad-Reantaso et al., 2005). There is insufficient information on the type of fish pathogens affecting aquaculture systems in Uganda thus making management of disease outbreaks difficult. Fish diseases are known to cause economic losses, reduced growth and increased cost of production (Faruk et al., 2004).Bacteria affect the health of both wild and 
farmed fish and Edwardsiella species are known pathogens affecting fish populations worldwide (Austin and Austin, 1987; Abowei \& Briyai, 2011; Park et al., 2012).

Edwardsiella tarda is the causative agent of Edwardsiellosis in fish, characterized by systemic hemorrhagic septicemia, internal abscesses and skin lesions (Ewing et al., 1965). The bacterium is opportunistic in nature, and disease outbreaks occur when poor environmental conditions prevail like overcrowding, poor water quality conditions, high organic content and high temperature (Mohanty and Sahoo, 2007). These factors influence the production of substances such as haemolysin, siderophore, superoxide dismutase, extracellular products and intracellular components that contribute to E. tarda pathogenicity and also expression of the two protein secretion systems that are involved in E. tarda virulence (Hossain et al., 2010; Guijarroet al., 2015; Huicab-Pech et al., 2016).

Occurrence of Edwardsiella species in farmed Nile tilapia and African catfish has been reported in Uganda but partially characterized to genus level (Walakira et al., 2014). Its prevalence in aquaculture systems is reported to vary with ponds not exceeding $5 \%$, and tanks ranging between 50-70\% (Mohanty and Sahoo, 2007; Joh et al., 2010). Edwardsiella tarda is also zoonotic causing gastroenteritis and skin lesions in humans (Park et al., 2012). Edwardsiella tarda is a facultative intracellular pathogen but its pathogenicity in host cells is not clearly understood (Xu and Zhang, 2014).However, its virulence factors are reported to enhance the bacterial survival, and pathogenesis in hosts. Therefore, identification of virulence-related genes is essential for explaining the pathogenesis of this bacterium.

\section{Methods and Materials}

The study was conducted in Wakiso District, central Uganda $\left(0^{\circ} 4^{\prime} \mathrm{S}, 32^{\circ} 45^{\prime} \mathrm{E}\right)$ (Figure 1).

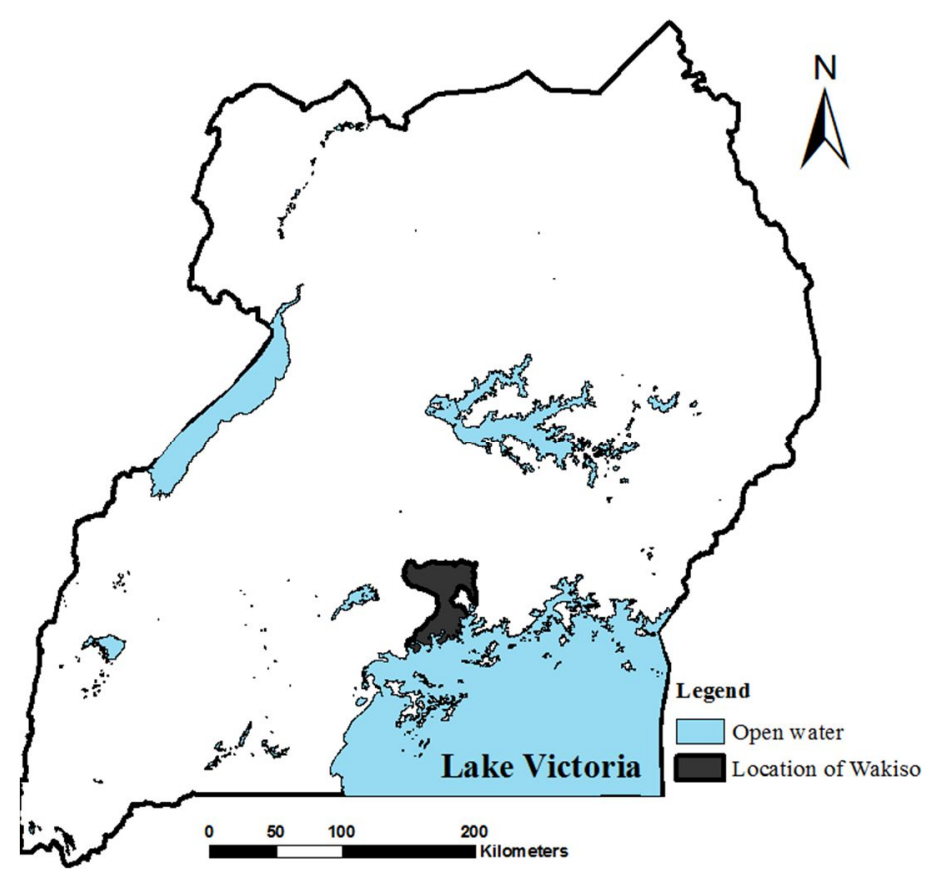

Figure 1. Map of Uganda showing the location of Wakiso District 
Fish farming is one of the main economic activities in the district. Samples were collected from 17 active commercial and subsistence fish farms with ponds, tanks and cages. The study applied a cross-sectional study design. Fish farms were purposively selected, the inclusion criteria being history of disease outbreaks during the study period and willingness of the farmer to participate in the study. Simple random sampling technique was applied to select clinically healthy fish, whereas in case of disease occurrence, sick fish were purposively selected from the culture system.

Healthy and sick fish samples were collected and transported in sterile containers to the laboratory between September 2016 and February 2017. Necropsy on fish samples was conducted to examine external and internal lesions following procedures described by Noga (2010).

Samples of organs (liver, spleen and kidney) and swabs from gills and skin were collected and subjected to bacteriological examination following methods described by Noga (2010) Samples were homogenized, inoculated on Xylose Lysine Desoxycholate (XLD) agar plates and incubated at $28^{\circ} \mathrm{C}$ for 36 hours after which they were examined for primary cultures. A welldifferentiated single black colony was picked and sub cultured on XLD agar to produce a pure culture which were subjected to various biochemical tests.

Identification of the bacterium was done using cultural and morphological characteristics, conventional biochemical tests and Analytical Profile Index (API 20E) system (BioMerieux, France) according to manufacturer's instructions and the biochemical profiles of the isolates from API 20E were determined. The isolates were preserved in cryovials containing Brain Heart Infusion broth and glycerol and then stored in the freezer at $-4^{\circ} \mathrm{C}$ until further testing.

Genomic DNA extraction was done using QIAamp DNA mini kit (Qiagen) following manufacturer's instructions. DNA concentration was measured using NanoDrop ND-1000 spectrophotometer (Thermo Fisher Scientific, Inc). The extracted DNA was preserved and stored at $-20^{\circ} \mathrm{C}$.

The 16S $r \mathrm{RN} A$ gene was amplified by Polymerase Chain Reaction (PCR) using the $16 \mathrm{~S}$ universal bacteria primers 27F (5' -AGAGTT'TGATCCTGGCTCAG-3') and 1492R (5'GGTTACCT'TGT'TACGACT'T-3') with the expected amplicon size of 1465bp (Lane 1991) from Invitrogen, Thermo Fisher Scientific (Waltham, MA USA). Polymerase Chain Reaction was performed in a thermo cycler (iCycler from Bio-Rad, United States of America). Each PCR reaction was performed in a final volume of $25 \mu$ l containing $2.5 \mu$ l of $10 \times$ reaction buffer (50

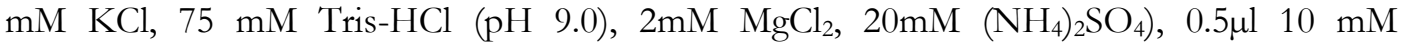
deoxyribonucleotide mix, $0.2 \mu \mathrm{l}$ of Taq DNA polymerase, $1 \mu \mathrm{l} 10 \mathrm{mM}$ of each forward and reverse primer, $2 \mu \mathrm{l}$ of DNA template and $16.8 \mu \mathrm{l}$ of sterile ultrapure water. PCR conditions included initial denaturation at $94^{\circ} \mathrm{C}$ for three minutes, followed by 30 cycles of amplification as follows; denaturation at $94^{\circ} \mathrm{C}$ for 30 seconds, annealing at $56^{\circ} \mathrm{C}$ for 30 seconds and extension at $72^{\circ} \mathrm{C}$ for two minutes. This was followed by a final extension step at $72^{\circ} \mathrm{C}$ for five minutes and left to stand at $4^{\circ} \mathrm{C}$ until collected for further analysis.

The PCR products were analysed on 1\% agarose gel (Ultrapure agarose from Invitrogen, Thermos Fisher Scientific) at 100 Volts for 60 minutes. The amplified DNA on the gel was visualized using Safe Imager ${ }^{\text {TM }}$ from Invitrogen and bands of interest excised using a scalpel blade for gel purification. ChemiDoc ${ }^{\text {TM }}$ XRS Molecular image (Bio Rad) was used for viewing and capturing gel pictures. The purified PCR products were sequenced with $16 \mathrm{~S} 27 \mathrm{~F}$ and $16 \mathrm{~S}$ 1492R universal bacteria primers by Sanger sequencing techniques at GATC Biotech, Germany using ABI genetic analyser. 
Both the forward and reverse sequences of the 16S $r R N A$ gene were edited in Bioedit to generate a consensus sequence. Basic Local Alignment Search Tool (BLAST) searches were carried out in GenBanks particularly the National Centre for Biotech Information (NCBI). Related sequences were obtained and multiple sequence alignments were performed using ClustalW algorithm. The alignments were used to construct a phylogenetic tree using MEGA 7.0 (Kumar et al., 2016) using the Neighbour-Joining method (Saitou and Nei, 1987). The gene sequences used in phylogenetic analysis are shown in Table 1.

Table 1. Isolates whose sequences were used in phylogenetic analysis

\begin{tabular}{lll}
\hline SN & Name of culture & Accession number \\
\hline 1 & E. tarda strain T1 & KX388234.1 \\
2 & E. tarda strain C6 & FJ607400.1 \\
3 & E. tarda strain UMT-WD-ON & FJ600537.1 \\
4 & E. tarda strain VMCU06 & KU860461.1 \\
5 & E. tarda strain C7-5m & HQ663902.1 \\
6 & E. tarda strain ATCC 15947 & KX866952.1 \\
7 & E. tarda strain 29-907R & M59159.1 \\
8 & P. shigelloides ATCC 14029 & KX388234 \\
9 & E. tarda strain SY-ED14 & X74688.1 \\
10 & P. shigelloides ATCC 14029T & KX828321.1 \\
11 & E. tarda strain 59-907R & LSHA01000019.1 \\
12 & Salmonella enterica subsp enterica ATCC 13076 & NZ_JMST01000035.1 \\
13 & E. coli ATCC 11775 & \\
\hline
\end{tabular}

Key: $\mathrm{E}=$ Edwardsiella, $\mathrm{P}=$ Pleisomonas

To characterize the virulence attribute of E. tarda isolate, seven virulence genes were screened for in this study. These included; gadB, muk, citC, fim $A$, esrB, katB and esaV. The genes were amplified by PCR using primers in Table 2.

Table 2. Primers used in the amplification of the virulence genes

\begin{tabular}{|c|c|c|c|}
\hline Target gene & Sequence $5 \longrightarrow 3{ }^{\prime}$ & $\begin{array}{l}\text { Product size } \\
\text { (bp) }\end{array}$ & Source \\
\hline $\operatorname{gadB}(\mathrm{F})$ & 5'- ATTTGGATTCCCGCTTTGGT-3' & \multirow[t]{2}{*}{583} & \multirow{2}{*}{$\begin{array}{l}\text { Wang et al. } \\
\text { (2012) }\end{array}$} \\
\hline $\operatorname{gadB}(\mathrm{R})$ & 5'- GCACGACGCCGATGGTGTTC-3' & & \\
\hline $\operatorname{muk}(\mathrm{F})$ & 5'- TTGCTGGCTATCGCTACCCT-3' & \multirow[t]{2}{*}{357} & \multirow{2}{*}{$\begin{array}{l}\text { Wang et al. } \\
\text { (2012) }\end{array}$} \\
\hline$m u k(\mathrm{R})$ & 5'- TTGCTGGCTATCGCTACCCT-3' & & \\
\hline $\operatorname{citC}(\mathrm{F})$ & 5'- TTTCCGTTTGTGAATCAGGTC-3' & \multirow[t]{2}{*}{591} & \multirow{2}{*}{$\begin{array}{l}\text { Wang et al. } \\
\text { (2012) }\end{array}$} \\
\hline $\operatorname{cit} C(\mathrm{R})$ & 5'- AATGTTTCGGCATAGCGTTG-3' & & \\
\hline $\operatorname{fim} A(\mathrm{~F})$ & 5'- CTGTGAGTGGTCAGGCAAGC-3' & \multirow[t]{2}{*}{441} & \multirow{2}{*}{$\begin{array}{l}\text { Wang et al. } \\
\text { (2012) }\end{array}$} \\
\hline $\operatorname{fim} A(\mathrm{R})$ & 5'- TAACCGTGTTGGCGTAAGAGC-3' & & \\
\hline $\operatorname{esr} B(\mathrm{~F})$ & 5'-TCGTTGAAGATCATGCCTTGC-3' & \multirow[t]{2}{*}{311} & \multirow{2}{*}{$\begin{array}{l}\text { Wang et al. } \\
\text { (2012) }\end{array}$} \\
\hline $\operatorname{esr} B(\mathrm{R})$ & 5'-TGCTGCGGGCTTTGCTT-3' & & \\
\hline katB(F) & 5'-CTTAGCCATCAGCCCTTCC-3' & \multirow[t]{2}{*}{1417} & \multirow{2}{*}{$\begin{array}{l}\text { Wang et al. } \\
\text { (2012) }\end{array}$} \\
\hline katB(R) & 5'-GCGAGTGCCGTAGTCCTT-3' & & \\
\hline$e s a V(\mathrm{~F})$ & 5'-GGTCAATAGCTGGCTACACAA-3' & \multirow[t]{2}{*}{955} & \multirow[t]{2}{*}{ Li et al. (2010) } \\
\hline $\operatorname{esa} V(\mathrm{R})$ & 5'-GCGCCTCAGCGAGTATGCGAT-3' & & \\
\hline
\end{tabular}


PCR reaction was performed in a final volume of $25 \mu \mathrm{l}$ containing $0.25 \mu \mathrm{l}$ of $10 \times$ reaction buffer (5 mM KCl, 7.5 mM Tris- $\left.\mathrm{HCl}(\mathrm{pH} 9.0), 0.2 \mathrm{mM} \mathrm{MgCl}_{2}, 2 \mathrm{mM}\left(\mathrm{NH}_{4}\right)_{2} \mathrm{SO}_{4}\right), 0.05 \mu \mathrm{l} 1 \mathrm{mM}$ deoxyribonucleotide mix, $0.02 \mu \mathrm{l}$ of Taq DNA polymerase, $0.1 \mu \mathrm{l} 1 \mathrm{mM}$ of each forward and reverse primer, $0.2 \mu \mathrm{l}$ of DNA template and $1.68 \mu$ lof sterile ultrapure water.

The PCR program was as follows; initial denaturation at $94^{\circ} \mathrm{C}$ for three minutes, followed by 32 cycles of denaturation at $94^{\circ} \mathrm{C}$ for one minute, annealing at $55^{\circ} \mathrm{C}$ for $\operatorname{cit} \mathrm{C}$, muk, esr, $58^{\circ} \mathrm{C}$ for katB, $57^{\circ} \mathrm{C}$ for $\operatorname{gadB}$, and $60^{\circ} \mathrm{C}$ fim $A$ for one minute, extension $72^{\circ} \mathrm{C}$ for one minute; and final extension at $72^{\circ} \mathrm{C}$ for ten minutes and left to stand at $4^{\circ} \mathrm{C}$ until further analysis.

PCR products were run on $1 \%$ agarose gel at 100 Volts for 60 minutes. The amplified products on the gel were observed and captured using ChemiDoc ${ }^{\mathrm{TM}}$ XRS Molecular image (Bio Rad).

Drug susceptibility of the isolate to various commonly used antibiotics was done using the Kirby Beurdisc diffusion method according to Hudzicki (2009).Standard antibiotic discs (Hardy diagnostics, USA) containing Chloramphenicol $(30 \mu \mathrm{g})$, Cefazolin $(30 \mu \mathrm{g})$, Gentamycin (10 $\mu \mathrm{g})$, Ceftriaxone $(30 \mu \mathrm{g})$, Oxacillin $(1 \mu \mathrm{g})$, Nalidixic acid $(30 \mu \mathrm{g})$, Tetracycline (30 $\mu \mathrm{g})$, Ciprofloxacin (5 $\mu \mathrm{g})$, Imipenem $(10 \mu \mathrm{g})$, Erythromycin $(15 \mu \mathrm{g})$, Vancomycin $(30 \mu \mathrm{g})$, Cefotaxine $(30 \mu \mathrm{g})$, Ampicillin $(10 \mu \mathrm{g})$, Trimethoprim-sulfamethoxazole $(25 \mu \mathrm{g})$, Amoxillin/Clav. Acid $(30 \mu \mathrm{g})$ and Penicillin $(10 \mu \mathrm{g})$ were used. The isolate was cultured on nutrient agar and incubated at $25{ }^{\circ} \mathrm{C}$ for 24 hours after which single colonies were emulsified in physiological saline $0.85 \%$ to obtain a bacterial suspension, with turbidity that corresponded to $0.5 \mathrm{McFarland} s$ standards (BioMerieux) that gives an approximate bacterial concentration of $1 \times 10^{6} \mathrm{CFU} / \mathrm{ml}$. The standardized innoculum was evenly streaked on Mueller-Hinton Agar plates onto which different antibiotic susceptibility discs were placed and incubated at $25{ }^{\circ} \mathrm{C}$ for 24 hours. After, diameters of zones of inhibition were measured using a ruler in millimetres to determine the susceptibility of the isolate to the drugs, which was recorded as resistant, sensitive or intermediately sensitive according to CLSI/NCCLS standards (CLSI, 2006; CLSI, 2015).

\section{Results}

\section{Clinical and Post Mortem Examination}

A total of 81 Nile tilapia and 30 African catfish including healthy, moribund and recently died fish were collected from selected fish farms in Wakiso district, Uganda between September 2016 and February 2017. Of the examined fish, one Nile tilapia had ascites and petechial abdominal haemorrhages whereas three African catfish showed signs of abnormalities including petechial haemorrhages on the skin and fins, lordosis, a pale liver and ulcers on the belly and opercula region (Figure 2).

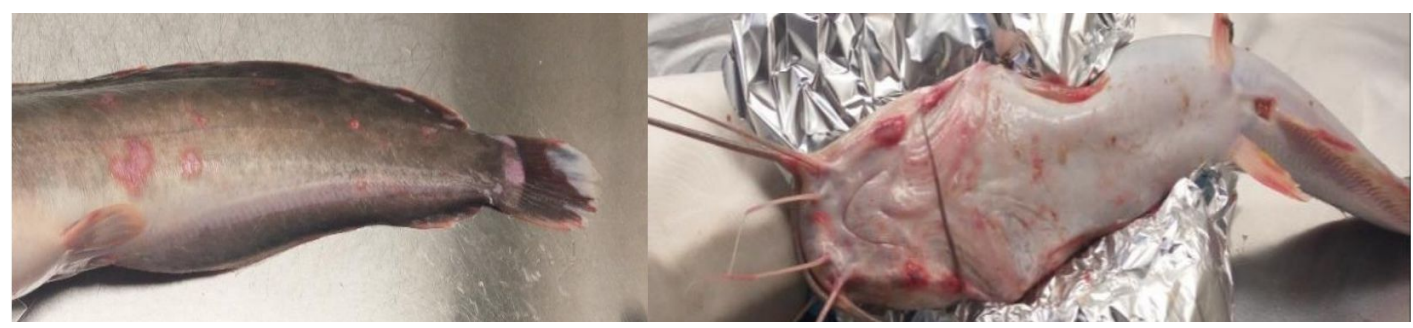

Figure 2. Haemorrhages and ulcers on farmed African catfish (Clarias gariepinus) 


\section{Phenotypic and Genotypic Identification}

Out of 111 fish samples, eight E. tarda suspect isolates were identified from four Nile tilapia and four African catfish using conventional biochemical tests. On culturing, clear colonies with black centres surrounded with reddened media were produced on Xylose Lysine Deoxycholate (XLD) media after 36 hours at $28^{\circ} \mathrm{C}$ expected to be E. tarda.

Microscopic examination of the gram-stained smears of the colonies revealed gram negative bacilli and the wet mounts of these colonies showed motile rods. Results of the biochemical tests are shown in Table 3. The results showed that the isolates were biochemically homogenous except for variations in the MR and VP tests as only two isolates tested positive for MR and negative for VP.

Table 3. Phenotypic properties of the eight suspect Edwardsiella tarda isolates

\begin{tabular}{|c|c|c|c|c|c|c|c|c|}
\hline \multirow{2}{*}{ Test } & \multicolumn{8}{|c|}{ Isolate IDs } \\
\hline & O.n 1 & O.n 2 & O.n 3 & O.n 4 & C.g 1 & C.g 2 & C.g 3 & C.g4 \\
\hline Gram stain & - & - & - & - & - & - & - & - \\
\hline Oxidase & - & - & - & - & - & - & - & - \\
\hline Indole production & + & + & + & + & + & + & + & + \\
\hline Citrate & - & - & - & - & - & - & - & - \\
\hline Motility & + & + & + & + & + & + & + & + \\
\hline Methyl Red & + & - & - & - & + & - & - & - \\
\hline Voges-Proskaeur & - & + & + & + & - & + & + & + \\
\hline Esculin hydrolysis & - & - & - & - & - & - & - & - \\
\hline Gelatin hydrolysis & - & - & - & - & - & - & - & - \\
\hline Urease & - & - & - & - & - & - & - & - \\
\hline Lactose utilization & - & - & - & - & - & - & - & - \\
\hline $\mathrm{H}_{2} \mathrm{~S}$ production & + & + & + & + & + & + & + & + \\
\hline
\end{tabular}

Key: O.n - Oreochromis niloticus, C.g - Clarias gariepinus, + - positive result, -- negative result)

Only one isolate was identified to be E. tarda at 99.4\% using the Analytical Profile Index (API) 20E kit with code number 4744000 . The isolate tested positive for citrate utilization unlike in the conventional biochemical tests. The seven isolates identified as E. tarda in the biochemical tests were identified by the API 20E kit as Plesiomonas shigelloides, which is a fish pathogen belonging to family Enterobacteriaceae (Austin and Austin, 2007).

Identification of the suspected E. tarda isolate was further validated by amplification of the $16 \mathrm{~S} r \mathrm{RN} A$ gene sequencing and BLAST searches.

\section{Phylogenetic Analysis}

Comparison of the E. tarda isolate with known 16S $r R N A$ sequences in the GenBank database using the BLAST program showed that the isolate had a $99.9 \%$ similarity to those of other members of E. tarda (Figure 3). 


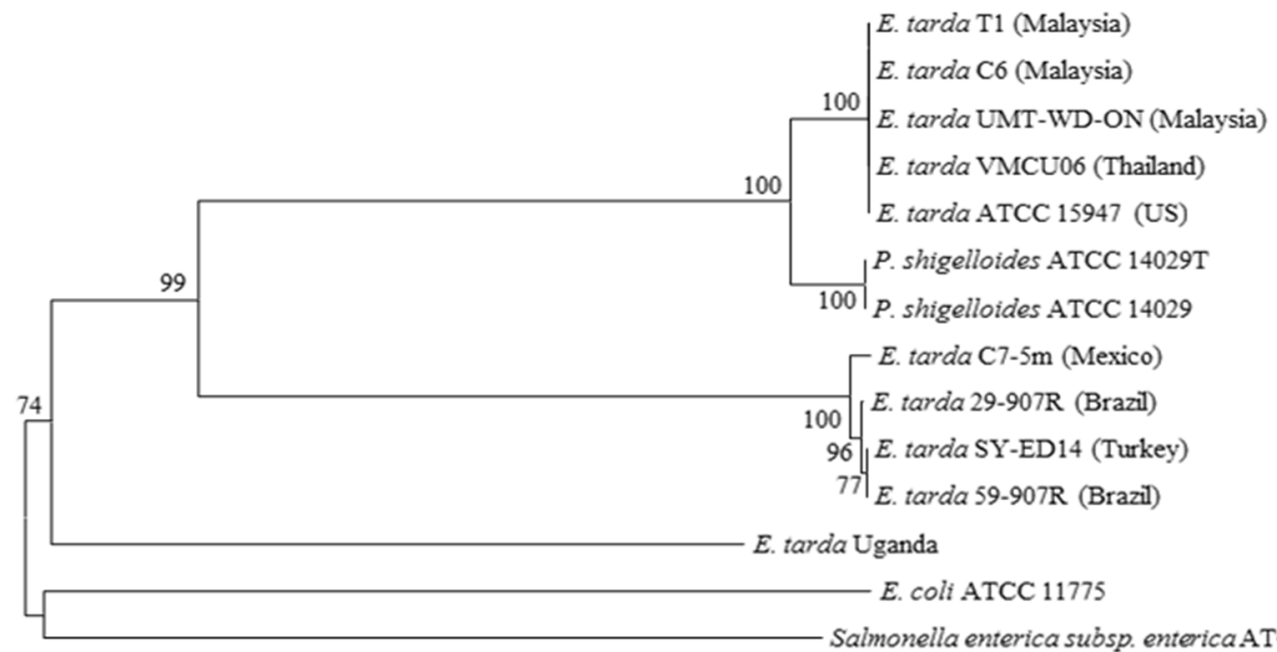

Salmonella enterica subsp. enterica ATCC 13076

20

Figure 3. Molecular phylogenetic tree for the genetic relationship among the isolates based on the nucleotide sequence of the $16 \mathrm{~S} r R N A$ gene

Note: The bootstrap process was repeated 500 times and the values are shown at major nodes in the tree. The scale bar is for a genetic distance marker (number of replacement nucleotides per site).

The taxonomic status, strain collection numbers and GenBank accession numbers of strains used in phylogenetic analysis are shown in Table 1.The percentage of replicate trees in which the associated taxa clustered together in the bootstrap test (500 replicates) are shown next to the branches (Felsenstein, 1985).

\section{Virulence genes harboured by Edwardsiella tarda}

Six genes namely; CitC, muk, gadD, esrB, katB and $\operatorname{fim} A$ of the seven virulence genes screened for were present in the E. tarda that was isolated in this study (Figure 4). 


\section{$\begin{array}{llllllllllllll}M & 1 & 2 & 3 & 4 & 5 & 6 & 7 & 8 & 9 & 10 & 11 & 12 & M\end{array}$}

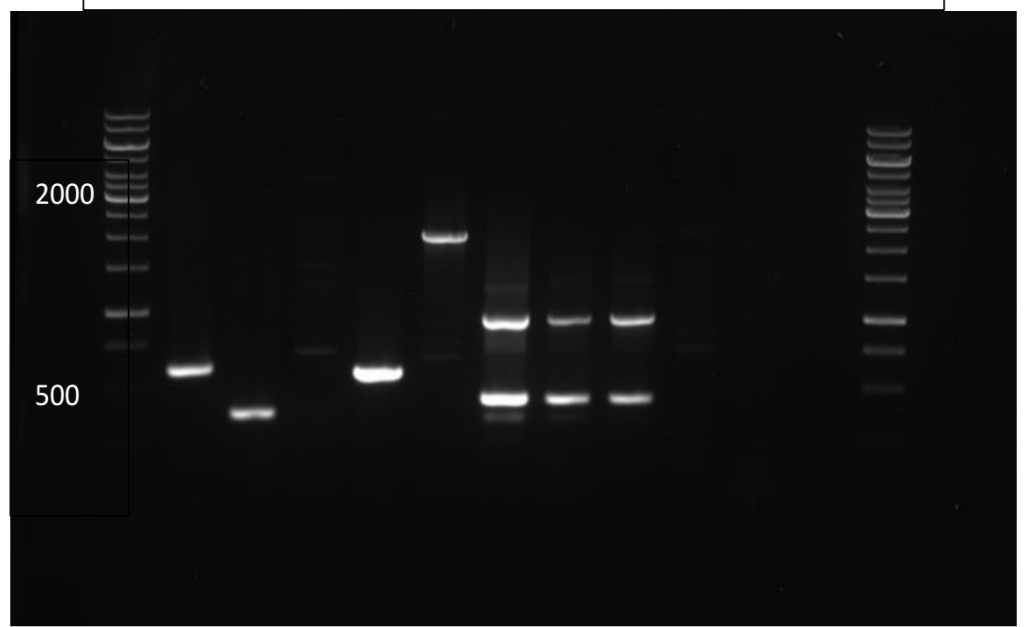

Figure 4. Agarose Gel electrophoresis of amplified virulence genes for the isolated E. tarda

Key: Lanes M - DNA marker, lane 1 -citC, lane $2-m u k$, lane 3 -esrB, lane $4-g a d B$, lane $5-k a t B$, lanes 6, 7 and 8 -fimA and esaV, Lanes 9 to 12 - blank

\section{Antibiotic susceptibility of the isolate}

It was found that the isolate was resistant to Oxacillin, Vancomycin and Penicillin, intermediately sensitive to Tetracycline and Erythromycin whereas it was sensitive to Chloramphenicol, Cefazolin, Gentamycin, Ceftriaxone, Nalidixic acid, Ciprofloxacin, Imipenem, Cefotaxime, Ampicillin, Trimethoprim-sulfamethoxazole and Amoxycillin (Table 4).

Table 4. Antibiotic susceptibility of the E. tarda isolate

\begin{tabular}{llll}
\hline Antibiotic discs & Disc code & Concentration $(\mu \mathrm{g})$ & Status \\
\hline Chloramphenicol & $\mathrm{C}$ & 30 & $\mathrm{~S}$ \\
Cefazolin & $\mathrm{CZ}$ & 30 & $\mathrm{~S}$ \\
Gentamycin & $\mathrm{GM}$ & 10 & $\mathrm{~S}$ \\
Ceftriaxone & $\mathrm{CRO}$ & 30 & $\mathrm{~S}$ \\
Oxacillin & $\mathrm{OX}$ & 1 & $\mathrm{R}$ \\
Nalidixic acid & $\mathrm{NA}$ & 30 & $\mathrm{~S}$ \\
Tetracycline & $\mathrm{Te}$ & 30 & $\mathrm{I}$ \\
Ciprofloxacin & $\mathrm{CIP}$ & 5 & $\mathrm{~S}$ \\
Imipenem & $\mathrm{IPM}$ & 10 & $\mathrm{~S}$ \\
Erythromycin & $\mathrm{E}$ & 15 & $\mathrm{I}$ \\
Vancomycin & $\mathrm{Va}$ & 30 & $\mathrm{R}$ \\
Cefotaxime & $\mathrm{CTX}$ & 30 & $\mathrm{~S}$ \\
Ampicillin & $\mathrm{Am}$ & 10 & $\mathrm{~S}$ \\
Trimethoprim-sulfamethoxazole & $\mathrm{SXT}$ & 25 & $\mathrm{~S}$ \\
Amoxillin/Clav. Acid & $\mathrm{AmC}$ & 30 & $\mathrm{~S}$ \\
Penicillin & $\mathrm{P}$ & 10 & $\mathrm{R}$ \\
\hline Key: & & &
\end{tabular}

Key: S - sensitive, R - resistant, I - intermediate 


\section{Discussion}

This is the first report on Edwardsiella tarda as a fish pathogen in Uganda. The information generated on virulence genes and its susceptibility to selected antibiotics is important for its management in aquaculture systems.

Although there is limited information about the disease occurrence in Uganda, Edwardsiella tarda is a significant pathogenic bacterium known to cause Edwardsiellosis in fresh and marine fish species both cultured and wild fish (Bullock and Herman, 1985; Mohanty and Sahoo, 2007). The disease leads to economic losses due to massive mortalities and reduced marketability of infected fish across the world (Faruk, 2004; Abraham et al., 2015). The present study established the occurrence of E. tarda infection at a rate of $7.2 \%$ by bacteriology and molecular technique confirmed E. tarda at a rate of $0.9 \%$ in Nile tilapia and African catfish farmed in Wakiso District in Uganda. A prevalence of $8.3 \%$ at farm level by bacteriology and conventional biochemical tests has been reported, suggesting involvement of the bacterium in disease occurrence in the country (Wamala et al., 2018). Similar findings were reported in Ethiopia where occurrence of E. tarda-like species was 7.6\% from clinically healthy tilapia (Nemo et al., 2017). The two studies suggest difficulties in differentiating the bacterium from other phenotypically and biochemically related bacteria. In this study, molecular identification of the isolates suggests that bacteriological and convention biochemical methods may be less specific in identifying E. tarda and related bacteria to species level. In that regard, E. tarda positive cases reported basing on these phenotypic methods might be E. tarda like species.

Pathological changes observed in the O. niloticus that had the confirmed E. tarda isolate were ascites and petechial haemorrhages. The observed pathological lesions were similar to what is reported for E. tarda infections in fish elsewhere (El-Refaey, 2013; El-Seedy et al., 2015). However, edwardsiellosis clinical signs and pathological lesions are not reliable at arriving to a conclusive diagnosis as several bacterial infections present with similar features (Mohanty and Sahoo, 2007). Furthermore, infected fish with or without any clinical signs of disease are equally important as they may carry pathogens resulting into a risk of spreading the disease to other species including humans. Therefore, detection of these pathogens is crucial for their effective prevention and control (Castro et al., 2014).

In the current study, basing on the culture and morphological examination, the findings were suggestive of E. tarda species similar to observations made by other researchers who isolated E. tarda from cultured freshwater tilapia, African catfish, chinook salmon and sharp snout sea bream (El-Refaey, 2013; Katharios et al., 2015; Abraham et al., 2015; Eman et al., 2016) indicating no variation in the phenotypic characters of the pathogen.

Regarding the biochemical findings, generally were similar to observations made by other studies for E. tarda organisms (Joh et al., 2010; El-Refaey, 2013; El-Seedy et al., 2015; Griffin et al., 2013; Abraham et al., 2015; Eman et al., 2016). However, there were variations in the MR and VP tests as only two isolates tested positive for MR and negative for VP as indicated in Table 3. These results were not in agreement with any literature and this could possibly suggest involvement of other species. However, it has been reported that variations in phenotypic characteristics do exist and being attributed to the presence or absence of plasmids that control the metabolic traits of the phenotypic characteristics of the isolates (Acharya et al., 2007; Das et al., 2014).

One of the key finding from this study was the identification of P. shigelloides in most samples, in which both cultural and biochemical tests indicated E. tarda infection. This suggests that morphological and biochemical identification using conventional bacteriology techniques were 
inconclusive in discriminating between E. tarda and P. shigelloides. API 20E kit test indicated only one isolate to be E. tarda at $99.4 \%$ of the eight isolates identified as E. tarda positive by the conventional biochemical tests. According to Buller (2004), differences in reactions occur between the API system and conventional biochemical tests and this is especially reported in decarboxylases, citrate, urea, indole and Voges-Proskeur tests. However, API test kits also have their limitations in bacteria identification that more definitive identification techniques such as PCR and sequencing are quite often preferred.

Phylogenetic analysis done in the current study separated the E. tarda strains in two groups without placing E. tarda isolated in this study in any group (Figure 3). One group clustered with P. shigelloides with high bootstrap support (100\%). Pleisomonas shigelloides is deep rooted in the family Enterobacteriaceae and is aligned closer to E. tarda (Janda et al., 2016).Hence, this could explain the possible misidentification of E. tarda on biochemical tests as could have been the case in the current study and probably some other studies elsewhere. The second group shares greater similarity to the E. tarda isolate from this study with bootstrap support of $74 \%$ than the first group. These findings concur with those of other comparative phylogenomic studies that identified two distinct genetic groups of E. tarda (Panangala et al., 2006; Griffin et al., 2013). This finding therefore, suggests that the E. tarda isolate from this study is genetically distant from those from the GenBank that were included in this study.

In our study, six of the known E. tarda virulence genes screened for were present in the isolated E. tarda which were; citC, muk, gadB, katB, esaV and fim A. Two of these genes (muk and gadB) were also detected by Eman et al. (2016) and are believed to be specific to pathogenic $E$. tarda. According to literature, detected genes in this study are regarded as main virulence genes. gadB and katB provide resistance to the bacterium against host phagocyte killing activity, fim $A$ enables cell adhesion, intracellular survival and replication of the bacterium in the host and muk is a putative killing factor (Mohanty and Sahoo, 2007; Katharios et al., 2015). It was also suggested that the presence of fim $A$ gene indicates the ability of E. tarda to bind to specific receptors in fish hence defining the site of entry and colonization. The most important properties for initiation of E. tarda infection process is the presence of surface structures which mediate motility, adherence and pathogen-host recognition. (Wang et al., 2009). This implies that the isolated E. tarda is potentially pathogenic to fish provided conducive environment prevails.

The detected virulence genes are known to be present only in virulent strains and therefore they are considered as biomarkers in the diagnosis of pathogenic E. tarda. These genes are used in determining how pathogenic bacteria interact with host to cause systemic infections and vaccine development as they are used in designing novel therapeutics and common antigens (Méndez et al., 2012). Although the current study did not assess the virulence of the isolate based on in vivo experiments, the presence of these virulence genes and observed clinical signs could indicate the presence of edwardsiellosis in farmed fish in Uganda.

Resistance to Vancomycin, Oxacillin and Penicillin was also observed by Wamala et al. (2018), however this is typical of all members of family Enterobacteriaceae (Stock and Wiedemann, 2001). This resistance is attributed to their outer membranes that resist permeability of these antibiotics. The anterior channel size of the porins is broader than the molecular size of Penicillin hence its hydrophobicity makes it impossible to cross the outer membrane (Stock and Wiedemann, 2001).

The isolate's sensitivity to Gentamycin, Nalidixic acid, Ciprofloxacin, Cefotaxime and Trimethoprim-sulfamethoxazole was also observed by Akinbowale et al. (2006). However, their study found E. tarda to be resistant to Ampicillin, Amoxycillin, Chloramphenicol, Tetracycline and Erythromycin. Abdel-Latif and Sedeek (2017) found, as in this study, E. tarda to be less 
sensitive to Erythromycin and Oxytetracycline and sensitive to Gentamycin and Ciprofloxacin although, unlike in this study, they found the bacteria to be resistant to Ampicillin. Results of this study are in contrast to some studies for example Ogbonne et al. (2018) who found E. tarda to be resistant to Amoxicillin, Chloramphenicol and Nalidixic acid and intermediately sensitive to Gentamycin. This resistance could either be possibly attributed to the presence of plasmids or presence of naturally occurring resistant bacteria in the aquatic sediments. However, frequent use of antibiotics in Uganda has been reported in veterinary practices for treatment of infectious diseases, prophylaxis and feed additives (UNAS et al., 2015) which could explain the resistance to Oxacillin, Vancomycin and Penicillin.

Overuse and misuse of antimicrobial agents lead to emergence of antimicrobial resistance in aquatic pathogens. Fortunately, results of this study show low acquired antibiotic resistance, which are in agreement with findings of Wamala et al. (2018). This could be because, according to UNAS et al. (2015), antibiotics are not widely used in Ugandan aquaculture for therapeutic purposes as their use is only for research and is strictly regulated.

\section{Conclusion}

This study confirmed occurrence of E. tarda in farmed Nile tilapia and African catfish in Uganda. Isolation and characterization of E. tarda from farmed fish is important information for the industry as effective prevention and control strategies for this pathogen can now be developed. Further studies should be conducted to understand the synergistic effect of E. tarda, and the zoonotic impact on consumers and fish practitioners.

\section{Acknowledgements}

The financial support from the Norwegian Agency for Development Cooperation (NORAD) through the Training and Research in Aquatic and Environmental Health in Eastern and Southern Africa (TRAHESA; TAN_13/0027) is highly acknowledged. Special thanks to Mr Joseph Sekkayi (Fisheries Officer of Wakiso district) and the entire staff of Microbiology laboratory of the College of Veterinary Medicine Animal Resources and Biosecurity, Makerere University for their enormous contribution to this research work.

\section{References}

Abdel-Latif, H.M.R. and Sedeek, E.K., 2017. Diversity of enterobacteriaceae retrieved from diseased cultured Oreochromis niloticus. International Journal of Fisheries and Aquatic Studies, 5(1): 29-34.

Abowei, J.F.N. and Briyai, O.F., 2011. A Review of Some Bacteria Diseases in Africa Culture Fisheries, Asian Journal of Medical Sciences, 3(5):206-217.

Abraham, T.J., Mallick, P.K., Adikesavalu, H. and Banerjee, S., 2015. Pathology of Edwardsiellatarda Infection in African Catfish, Clarias gariepinus (Burchell 1822), Fingerlings, Archives of Polish Fisheries, 23:14-48. 
Acharya, M., Maiti, N.K., Mohanty, S., Mishra, P. and Samanta, M., 2007. Genotyping of Edwardsiella tarda isolated from freshwater fish culture system, Comparative Immunology, Microbiology and Infectious Diseases, 30:33-40.

Akinbowale, O. L., Peng, H. and Barton, M., 2006. Antimicrobial resistance in bacteria isolated from aquaculture sources in Australia, Journal of Applied Microbiology, 100:1103-13.

Austin, B. and Austin, D.A., 1987. Enterobacteriaceae Representatives. Bacterial Fish Pathogens: Disease in Farmed and Wild Fish, Ellis Horwood Ltd., Chichester England pp. 196-224.

Austin, B. and Austin, D.A., 2007. Bacterial Fish Pathogens: Disease in Farmed and Wild Fish, Praxis Publishing Ltd, Chichester, UK pp.

Bondad-Reantaso, M.G., Subasinghe, R.P., Arthur, J.R., Ogawa, K., Chinabut, S., Adlard, R., Tan, Z. and Shariff, M., 2005. Disease and health management in Asian aquaculture. Veterinary Parasitology, 132(3-4):249-72.

Buller, N.B., 2004. Bacteria and Fungi from Fish and Other Aquatic Animals: a Practical Identification Manual, CABI, Oxfordshire, UK2 ${ }^{\text {nd }}$ edition. 920pp.

Bullock, G.L. and Herman, R.L., 1985. Edwardsiella Infections of Fishes. US Fish \& Wildlife Publications, Paper 132. [http://digitalcommons.unl.edu/usfwpubs/132].

Castro, N., Toranzo, A.E. and Magariños, B., 2014. A Multiplex PCR for the Simultaneous Detection of Tenacibaculum maritimum and Edwardsiella tarda in Aquaculture, International Microbiology, 17:111-117.

CLSI, 2006. Methods for dilution of antimicrobial susceptibility tests for bacteria that grow aerobically: approved standard M7-A7. 7th ed. Wayne: Clinical and Laboratory Standards Institute.

CLSI, 2015. Methods for antimicrobial dilution and disk susceptibility testing of infrequently isolated or fastidious bacteria, 3rd Ed. CLSI guideline M45. Wayne: Clinical and Laboratory Standards Institute.

Das, B.K., Sahu, I. Kumari, S. Sadique, M. and Nayak, K.K., 2014. Phenotyping and Whole Cell Protein Profiling of Edwardsiella tarda Strains Isolated from Infected Freshwater Fishes, International Journal of Current Microbiology and Applied Science, 3:235-247.

El-Refaey, A.M.E., 2013. Studies on Major Bacterial Diseases Affecting Fish; Tilapia Oreochromisniloticus, Catfish Clariasgariepinusand Mullets in Port Said, Egypt with Special References to its Pathological Alterations, Researcher, 5:5-14.

El-Seedy, F.R., Radwan, I.A. Abd El-Galil, M.A. and Sayed, H.H., 2015. Phenotypic and Genotypic Characterization of Edwardsiella tarda Isolated from Oreochromis niloticus and Clarias gariepinus at Sohag Governorate, Journal of American Science, 11:68-75.

Eman, M.M., Omar, A.A.E. and Abdo, W.S., 2016. Insight into the Virulence-Related Genes of Edwardsiella tarda Isolated from Cultured Freshwater Fish in Egypt, World Veterinary Journal, 6:101-109.

Ewing, W.H., McWhorter, A.C., Escobar, M.R. and Lubin, A.H., 1965. Edwardsiella, a New Genus of Enterobacteriaceae Based on a New Species, E. tarda, International Bulletin of Bacterial Nomenclature and Taxonomy, 15:33-38.

FAO, 2018. FAO Fisheries and Aquaculture Circular No.C942 Revision 3

Faruk, M.A.R., Sarker, M.M.R., Alam, J. and Kabir, M.B., 2004. Economic Loss from Fish Diseases on Rural Freshwater Aquaculture of Bangladesh, Pakistan Journal of Biological Sciences, 7:2086-2091.

Felsenstein, J., 1985. Confidence limits on phylogenies: An approach using the bootstrap, Evolution, 39:783-791.

Griffin, M.J., Quiniou, S.M., Cody, T., Tabuchi, M. Ware, C., Cipriano, R.C., Mauel, M.J. and Soto, E., 2013. Comparative Analysis of Edwardsiella Isolates from Fish in the Eastern United 
States Identifies Two Distinct Genetic Taxa Amongst Organisms Phenotypically Classified as E. tarda, Veterinary Microbiology, 165:358-372.

Guijarro, J.A., Cascales, D., Garcia-Torrico, A.I., Garcia-Dominguez, M. and Mendez, J., 2015. Temperature-Dependent Expression of Virulence Genes in Fish-Pathogenic Bacteria, Frontiers in Microbiology, 6:700-711.

Hudzicki, J., 2009. Kirby-Bauer disk diffusion susceptibility test protocol. American Society for Microbiology.

Hossain, M.M., Mondal, S.A.S.M. and Kawai, K., 2010. Temperature Effects on Pathogenicity of Selected Edwardsiella tarda Strain to Japanese Eel, Anguilla japonica, Bangladesh Journal of Fisheries Research, 14:65-73.

Huicab-Pech, Z.G., Landeros-Sánchez, C., Castañeda-Chávez, M.R., Lango-Reynoso, F., López-Collado, C.J. and Platas-Rosado, D.E., 2016. Current State of Bacteria Pathogenicity and their Relationship with Host and Environment in Tilapia Oreochromis niloticus, Journal of Aquaculture Research and Development,7:428-438.

Janda, J.M., Abbott, S.L. and McIver, C.J., 2016. Plesiomonasshigelloides revisited, Clinical Microbiology Reviews, 29:349-374.

Joh, S., Kim, M., Kwon, H., Ahn, E., Jang, H. and Kwon, J., 2010. Characterization of Edwardsiellatarda Isolated from Farm-Cultured Eels, Anguilla japonica, in the Republic of Korea, Journal of Veterinary Medical Science, 73:7-11.

Katharios, P., Kokkari, C., Dourala, N. and Smyrli, M., 2015. First Report of Edwardsiellosis in Cage-Cultured Sharp snout Sea Bream, Diplodus Puntazzo from the Mediterranean, BMC Veterinary Research, 11:155-161.

Kumar. S., Stecher, G. and Tamura, K., 2016. MEGA7: Molecular Evolutionary Genetics Analysis version 7.0 for Bigger Datasets, Molecular Biology and Evolution, 33:1870-1874.

Lane, D.J., 1991. 16S/23S rRNA sequencing. In: Stackebrandt E, Goodfellow M, editors. Nucleic acid techniques in bacterial systematics, John Wiley and Sons. Chichester, pp. 115-175.

Li, G.Y., Li, J., Xiao, P., Guo, Y.H. and Mo, Z. L., 2010. Detection of type III secretion gene as an indicator for pathogenic Edwardsiella tarda, Letters in Applied Microbiology, 52:213-219.

Méndez, J., Reimundo, P., Pérez-Pascual, D., Navais, R., Gómez, E., Cascales, D. and Guijarro, J.A., 2012. An Overview of Virulence-Associated Factors of Gram-Negative Fish Pathogenic Bacteria, Health and Environment in Aquaculture, 5:133-156.

Mohanty, B.R. and Sahoo, P.K., 2007. Edwardsiellosis in fish: a brief review, Journal of Biosciences, 32:1331-1344.

Nemo, N., Sisay, T. and Abayneh, T., 2017. Isolation of Edwardsiella tarda-like species and its frequency of occurrence in freshwater fish harvested for human consumption from Lake Hawassa and crater lakes around Bishoftu, Ethiopia, African Journal of Fisheries Science, 5(6): 260-266.

Noga, E.J., 2010. Fish disease: diagnosis and treatment. Second edition, Wiley-Blackwell USA pp. 17-48.

Ogbonne, F.C., Ukazu, E.R. and Egbe, F.C., 2018. Antibiotics Resistance Pattern and Plasmid Profiling of Edwardsiella tarda Isolated from Heterobranchus longifilis, Journal of Biosciences and Medicines, 6:95-105.

Panangala, V.S., van Santen, V.L., Shoemaker, C.A. and Klesius, P.H., 2005. Analysis of 16S$23 \mathrm{~S}$ intragenic spacer regions (ISRs) of the $r \mathrm{RN} A$ operons in Edwardsiella ictaluri and Edwardsiella tarda isolates from fish, Journal of Applied Microbiology, 99:657-669.

Park, S.B., Aoki, T. and Jung, T.S., 2012. Pathogenesis of and Strategies for Preventing Edwardsiella tarda Infection in Fish, Veterinary Research, 43:67-78. 
Saitou, N. and Nei, M., 1987. The Neighbour-joining Method: A New Method for Reconstructing Phylogenetic Trees, Molecular Biology and Evolution, 4:406-425.

Stock, I. and Wiedemann, B., 2001. Natural Antibiotic Susceptibilities of Edwardsiella tarda, E. ictaluri, and E. hoshinae, Journal of Antimicrobial Agents and Chemotherapy, 45(8): 2245-2255.

UNAS, CDDEP, GARP-Uganda, 2015. Antibiotic Resistance in Uganda: Situation Analysis and Recommendations. Kampala, Uganda: Uganda National Academy of Sciences; Centre for Disease Dynamics, Economics \& Policy.

Walakira, J., Akoll, P., Engole, M., Sserwadda, M., Nkambo, M., Namulawa, V., Kityo, G., Musimbi, F., Abaho, I., Kasigwa, H., Mbabazi, D., Kahwa, D., Naigaga, I., Birungi, D., Rutaisire, J. and Majalija, S., 2014. Common fish diseases and parasites affecting wild and farmed Tilapia and Catfish in Central and Western Uganda, Uganda Journal of Agricultural Sciences, 15:113-125.

Wamala, S.P., Mugimba, K.K., Mutoloki, S., Evensen, Ø., Mdegela, R., Byarugaba, D.K. and Sørum, H., 2018. Occurrence and antibiotic susceptibility of fish bacteria isolated from Oreochromis niloticus (Nile tilapia) and Clarias gariepinus (African catfish) in Uganda, Journal of Fisheries and Aquatic Sciences, 21:6-16.

Wang, Q., Yang, M., Xiao, J., Wu, H., Wang, X., Lv, Y., Xu, L., Zheng, H., Wang, S., Zhao, G., Qin Liu, Q. and Zhang, 2009. Genome Sequence of the Versatile Fish Pathogen Edwardsiella tarda Provides Insights into its Adaptation to Broad Host Ranges and Intracellular Niches, PLOS ONE, 4: e7646.

Wang, X., Yan, M., Wang, Q., Ding, L. and Li, F., 2012. Identification of Edwardsiella tarda isolated from duck and virulence genes detection, African Journal of Microbiology Research, 6:4970-4975.

Xu, T. and Zhang, X., 2014. Edwardsiella tarda: an intriguing problem in aquaculture, Aquaculture, 431:129-135. 